\title{
A novel isoquinoline alkaloid, DD-carboxypeptidase inhibitor, with antibacterial activity isolated from Streptomyces sp. 8812. Part I: Taxonomy, fermentation, isolation and biological activities
}

\author{
Jolanta Solecka $^{1}$, Aleksandra Rajnisz ${ }^{1}$ and Agnieszka E Laudy ${ }^{2}$
}

A novel isoquinoline alkaloid of molecular formula $\mathrm{C}_{10} \mathrm{H}_{9} \mathrm{NO}_{4}$, labeled JS-1, was isolated from the culture broth of Streptomyces sp. 8812. It was purified by acetone protein precipitation from the culture supernatant, followed by anion exchange and C18 RP HPLC columns. JS-1 is an inhibitor of exocellular DD-carboxypeptidases/transpeptidases (DD-peptidases) 64-575 II from Saccharopolyspora erythraea 64-575 II, and R39 from Actinomadura R39. JS-1 exhibits activity against Gram-negative bacteria, such as Bordetella bronchiseptica, Stenotrophomonas maltophilia, Proteus vulgaris, P. mirabilis, Burkholderia cepacia and Acinetobacter baumanii, with MIC values $10-160 \mu \mathrm{g} \mathrm{ml}^{-1}$, and against Gram-positive bacteria, such as Staphylococcus aureus, with MIC values $40-206 \mu \mathrm{ml}^{-1}$.

The Journal of Antibiotics (2009) 62, 575-580; doi:10.1038/ja.2009.85; published online 28 August 2009

Keywords: antibacterial agent; DD-carboxypeptidase inhibitor; isoquinoline alkaloid; JS-1

\section{INTRODUCTION}

The increasing bacterial resistance to antibiotics is at present a serious therapeutic problem. Multiresistant pathogenic bacteria occur very frequently. ${ }^{1}$ Hence, there is a necessity for the discovery of new classes of antibiotics for the treatment of drug-resistant bacterial infections. Apart from combinatorial chemistry, rational drug design and computer-assisted design technology, one of the solutions to bacterial resistance involves screening for microorganisms producing novel antimicrobial drugs. ${ }^{2,3}$ Currently, the majority of antibacterial agents in clinical use are either microbial natural products or one of their analogs. ${ }^{4}$ Streptomycetes are well-known producers of antibiotics and other bioactive metabolites. More than half $(56 \%)$ of all bacterial metabolites consist of derivatives of amino acids, peptides, peptolides and polypeptides. ${ }^{5}$ The purpose of this study was to search for novel antimicrobial agents, specifically inhibitors of DD-peptidases (EC 3.4.16.4). DD-carboxypeptidases/transpeptidases are the enzymes involved in peptide cross-linking during the last stage of bacterial cell wall peptidoglycan biosynthesis. ${ }^{6,7}$ Enzymes participating in cell wall biosynthesis have proved to be excellent targets for antibacterial agents because the cell wall pathway is conserved among bacterial pathogens and is absent in mammalian cells. $\beta$-Lactam antibiotics are the most important class of DD-peptidases/penicillin-binding proteins inhibitors and antimicrobial agents. ${ }^{6}$ However, resistance mechanisms of patho- genic bacteria, for example, changes in penicillin-binding proteins and production of $\beta$-lactamases, render the $\beta$-lactam antibiotics ineffective. In our screening program for novel inhibitors of DD-peptidases from microbial secondary metabolites, we used DD-peptidase 64-575 $\mathrm{II}^{8,9}$ from our collection of streptomycetes strains. A novel compound having antibacterial activity, DD-peptidase inhibitor, labeled JS-1, a member of isoquinoline alkaloids, was isolated from the culture broth of Streptomyces sp. 8812. In this paper, we describe the taxonomy and fermentation of Streptomyces sp. 8812 and the isolation procedure of JS-1. We also characterize the biological properties of this compound. ${ }^{10}$ The physico-chemical properties and structure elucidation of JS-1 are described in the following paper of this issue. ${ }^{11}$ The structure of the discovered alkaloid is shown below (Figure 1).

\section{RESULTS AND DISCUSSION}

Taxonomy of the producing strain

The strain Streptomyces sp. 8812 forms well-developed and branching substrate mycelium and aeral mycelium. The culture characteristics and carbon utilization of sp. 8812 are shown in Table 1. Good growth was observed on inorganic salts-starch agar, on glycerol-asparagine agar and Czapek's agar. The best culture medium for this strain was yeast extract-malt extract agar and tyrosine agar on which it grew

${ }^{1}$ Independent Laboratory of Streptomycetes and Fungi Imperfecti, National Institute of Public Health—National Institute of Hygiene, Warsaw, Poland and ${ }^{2}$ Department of Pharmaceutical Microbiology, Medical University of Warsaw, Warsaw, Poland

Correspondence: Dr J Solecka, Independent Laboratory of Streptomycetes and Fungi Imperfecti, National Institute of Public Health—National Institute of Hygiene, Chocimska 24, Warsaw 00-791, Poland.

E-mail: jsolecka@pzh.gov.pl

Received 6 May 2009; revised 24 July 2009; accepted 3 August 2009; published online 28 August 2009 
<smiles>O=C1C=C2CC(C(=O)O)NC=C2C=C1O</smiles>

Figure 1 The structure of the alkaloid, JS-1.

Table 1 Cultural characteristics and carbon utilization of Streptomyces sp. 8812

\begin{tabular}{|c|c|c|c|c|}
\hline Medium & Growth & $\begin{array}{l}\text { Aerial } \\
\text { mycelium }\end{array}$ & $\begin{array}{l}\text { Reverse } \\
\text { side color }\end{array}$ & Melanin \\
\hline Yeast extract-malt extract agar & Abundant & R7a, R6a & Or3r & - \\
\hline Inorganic salts-starch agar & Good & Oc7m & O4b & - \\
\hline Glycerol-asparagine agar & Good & Oc7a & Oc7a & - \\
\hline Tyrosine agar & Abundant & R5a & R7s & + \\
\hline Czapek's agar & Good & Coo7c & Coo7c & - \\
\hline \multicolumn{5}{|l|}{ Carbon utilization } \\
\hline D-Glucose & ++ & & & \\
\hline D-Xylose & + & & & \\
\hline L-Arabinose & ++ & & & \\
\hline L-Rhamnose & - & & & \\
\hline D-Fructose & ++ & & & \\
\hline D-Mannitol & ++ & & & \\
\hline D-Sucrose & - & & & \\
\hline Raffinose & + & & & \\
\hline I-Inositol & - & & & \\
\hline Cellulose & - & & & \\
\hline
\end{tabular}

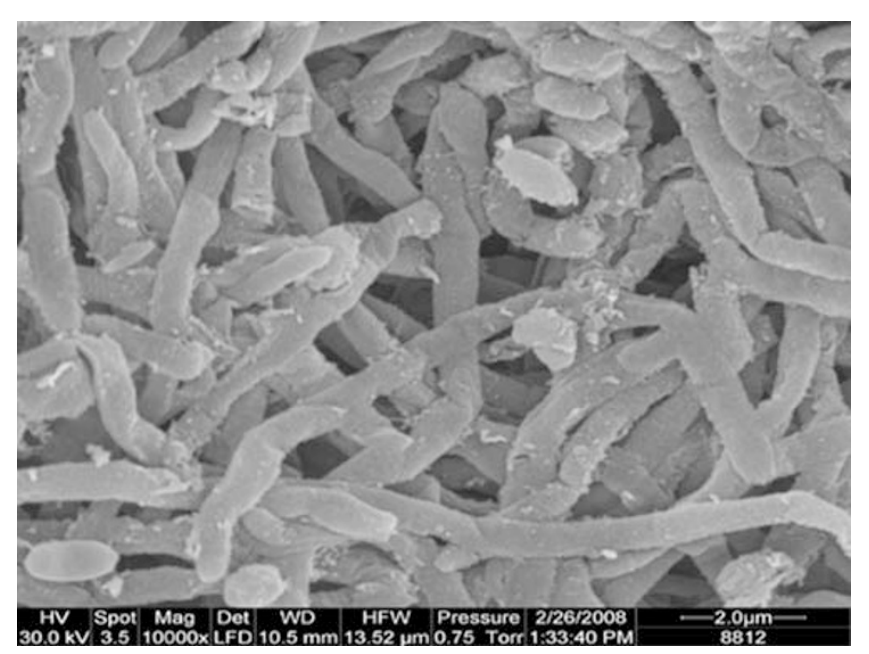

Figure 2 Scanning electron micrograph of the spore chain of Streptomyces sp. 8812 grown on yeast-malt agar for 14 days. Bar represents $2.0 \mu \mathrm{m}$.

abundantly. Substrate and aeral mycelium color were medium dependent. Spore chains were of the open loop (Retinaculum apertum) type with smooth surface and spore dimensions of $0.65-0.8 \mu \mathrm{m} \times 1.3-$ $1.5 \mu \mathrm{m}$ (Figure 2).

From the characteristics stated above, the strain 8812 was identified as Streptomyces sp. This strain was deposited in the Polish Collection

\author{
Culture broth $(5 \mathrm{~L})$ \\ । \\ Supernatant \\ I Protein precipitation with acetone \\ BioLogic System, IRA-400 (AcO-) \\ I 0-2 $\mathrm{M} \mathrm{AcOH}$ \\ BioLogic System, Atlantis dC18 \\ I 9-11\% phase $\mathrm{B}$ [phase $\mathrm{B}, \mathrm{CH}_{3} \mathrm{CN}-0.1 \%$ TFA, \\ । 30 : $70(\mathrm{v} / \mathrm{v})$ ]; phase A, $0.05 \%$ TFA \\ HPLC, Atlantis dC18 \\ I $2 \%$ phase $B$ [phase $\mathrm{B}, \mathrm{CH}_{3} \mathrm{CN}-0.05 \%$ TFA, \\ । $20: 80(\mathrm{v} / \mathrm{v})$ ]; phase A, $0.05 \%$ TFA \\ JS-1
}

Figure 3 Isolation and purification of JS-1 under guidance of DD-peptidase 64-575 II inhibition reaction.

of Microorganism, Wroclaw, under the name of Streptomyces sp. 8812, with an accession number $\mathrm{B} / 00017$.

The culture broth was centrifuged $\left(8000 \mathrm{~g}\right.$ for $60 \mathrm{~min}$ at $4{ }^{\circ} \mathrm{C}$; Beckman Coulter, Sykesville, MD, USA) to obtain the supernatant, followed by acetone precipitation of proteins (Figure 3 ). The precipitated proteins were centrifuged ( $8000 \mathrm{~g}$ for $30 \mathrm{~min}$ at $4{ }^{\circ} \mathrm{C}$; Beckman) and discarded. The acetone solution was evaporated under reduced pressure to afford an aqueous solution, which was frozen and lyophilized (24h, Beta 1-8, Christ, Osterode, Germany).

The crude material $(22 \mathrm{~g})$ was dissolved in deionized water $(200 \mathrm{ml})$, applied to an anion exchange resin IRA-400 $\left(\mathrm{AcO}^{-}\right)$(Supelco, Bellefonte, PA, USA) column $5 \times 25 \mathrm{~cm}$ and washed with deionized water (1.51). Chromatography was performed using the BioLogic system (Bio-Rad, Hercules, CA, USA) at flow rates of $9.9 \mathrm{ml} \mathrm{min}^{-1}$ and detection by UV absorption at $254 \mathrm{~nm}$. Elution was performed with a stepwise gradient of aqueous acetic acid $(0.5,1,2 \mathrm{M}, 11$ each) and $6 \mathrm{ml}$ fractions were collected. The active compound (fractions exhibiting an inhibitory effect on DD-peptidase activity) was eluted with $\sim 0.5 \mathrm{M}$ aqueous acetic acid and lyophilized to yield the partially purified material $(140 \mathrm{mg})$. This procedure was repeated 4 times and $560 \mathrm{mg}$ of the material was obtained.

Further purification of JS-1 was carried out by the BioLogic System (Bio-Rad) on a semi-preparative modified reversed-phase column (Atlantis, dC18, $10 \times 250 \mathrm{~mm}, 10 \mu \mathrm{m}$, Waters, Milford, MA, USA); UV detection at $214 \mathrm{~nm}$; flow rate of $4.7 \mathrm{ml} \mathrm{min}^{-1}$; mobile phase: isocratic phase A: $0.05 \%$ trifluoroacetic acid $(10 \mathrm{ml})$, and linear gradient from 0 to $19 \%$ of phase $\mathrm{B}$ (phase $\mathrm{B}$ was $\mathrm{CH}_{3} \mathrm{CN}-0.1 \%$ trifluoroacetic acid, 30:70 (v/v)), $175 \mathrm{ml}$. The most active fractions obtained at 9-11\% of phase B, exhibiting 100\% inhibition of DD-peptidase activity, were collected. The fractions eluted in 22 repeated runs were pooled and lyophilized to yield $40 \mathrm{mg}$ of powder.

This was then subjected to HPLC (Atlantis, dC18, $4.6 \times 250 \mathrm{~mm}$, $5 \mu \mathrm{m}$, Waters); detection by $\mathrm{UV}$ at $214 \mathrm{~nm}$; flow rate of $1 \mathrm{ml} \mathrm{min}^{-1}$; mobile phase: $2 \%$ phase B (B: $\mathrm{CH}_{3} \mathrm{CN}-0.05 \%$ trifluoroacetic acid, 20:80 (v/v)), phase A ( $0.05 \%$ trifluoroacetic acid). Under these conditions, JS-1 was eluted at a retention time of $30.4 \mathrm{~min}$. The fractions eluted in 80 repeated runs were pooled and lyophilized to yield $7 \mathrm{mg}$ of yellow powder.

Further purification of JS- 1 was carried out by the same procedure as described previously, namely, the detection by diode array detection (Figure 4). JS-1 of $5 \mathrm{mg}$ was obtained. 


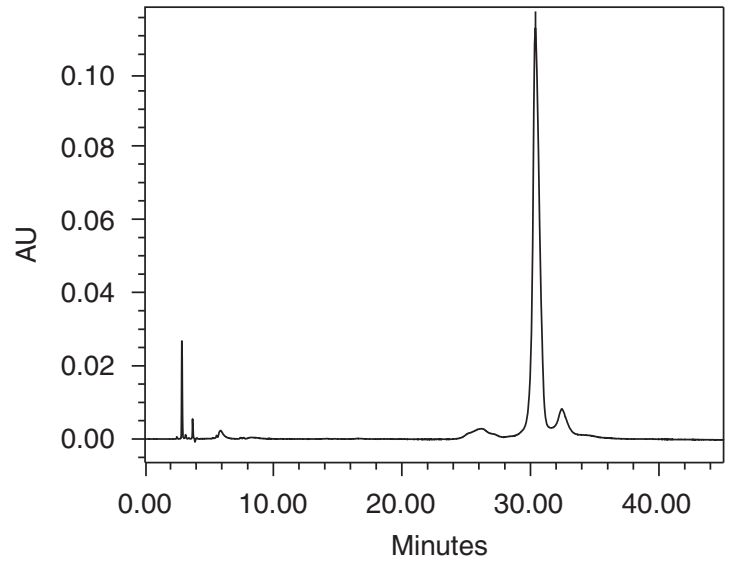

Figure 4 HPLC profile of the purified JS-1 compound.

\section{Inhibitory effect of JS-1 on DD-peptidases}

JS-1 exhibited inhibitory effects on DD-peptidases 64-575 II and R39. The concentrations of the compound necessary to inhibit DD-carboxypeptidases by $50 \%\left(\mathrm{IC}_{50}\right)$ were calculated. The $\mathrm{IC}_{50}$ values of JS- 1 for these enzymes were 4.7 and $6.0 \mu \mathrm{M}$, respectively. The $\mathrm{IC}_{50}$ values of $\beta$-lactam antibiotics for DD-carboxypeptidase 64-575 II were compared with the $\mathrm{IC}_{50}$ value of JS-1 for DD-carboxypeptidase 64-575 II, for example, the $\mathrm{IC}_{50}$ values of carbenicillin, cephalothin and imipenem for DD-carboxypeptidase 64-575 II were $1.4,1.1 \mu \mathrm{M}$ and $58 \mathrm{~nm}$, respectively. ${ }^{9}$ The $\mathrm{IC}_{50}$ value of 6 -aminopenicillanic acid for DDcarboxypeptidase $\mathrm{R} 39$ was comparable with the $\mathrm{IC}_{50}$ value of JS-1 for this enzyme. ${ }^{12}$ The $\mathrm{IC}_{50}$ values of $\beta$-lactam antibiotics such as 6-aminopenicillanic acid, carbenicillin and cephalothin for DD-carboxypeptidase R39 were $5.7,1.95 \mu \mathrm{M}$ and $42 \mathrm{nM}$, respectively. ${ }^{12}$ Until today, there have not been any described inhibitors of DD-peptidases from the group of isoquinoline alkaloids. It is assumed that JS-1 may inhibit cell wall biosynthesis by disturbing the cross-linking of peptidoglycan, analogous to the mechanism of action of $\beta$-lactam antibiotics.

\section{Inhibitory effect of JS-1 on $\beta$-lactamase}

As the examined alkaloid has been shown to inhibit DD-peptidase 64-575 II activity, similar to clavulanic acid, ${ }^{9}$ which is a known inhibitor of $\beta$-lactamases, an inhibition test was carried out for this enzyme. JS-1 did not show inhibitory activity against $\beta$-lactamase from Bacillus cereus.

\section{Inhibitory effect of JS-1 on common proteolytic enzymes}

To examine the specificity of the JS-1 compound, inhibition assays were performed for a range of common proteolytic enzymes. It was determined that at a concentration of $65 \mu \mathrm{M}$, the JS- 1 alkaloid causes a $100 \%$ inhibition of DD-peptidase 64-575 II and DD-peptidase R39, whereas the rest of the enzymes remained active even in a twofold higher concentration. Only pepsin lost $10 \%$ of its activity, whereas the activity of papain, a proteolytic enzyme with a disulfide bond in its active center, was inhibited by $7 \%$. The obtained results on the examination of the JS-1 alkaloid implied it to be a specific inhibitor of DD-peptidases.

\section{Hemolytic activity}

No hemolytic activity was observed on human erythrocyte.
Table 2 MICs and MBCs of alkaloid JS-1 against Gram(+), Gram(-) bacteria and yeast ${ }^{\mathrm{a}}$

\begin{tabular}{|c|c|c|}
\hline Microorganism & $M I C,\left(\mu g \mathrm{ml}^{-1}\right)$ & $M B C,\left(\mu g m l^{-1}\right)$ \\
\hline S. aureus ATCC 25923 & 80 & 80 \\
\hline S. aureus ATCC 43300 & 40 & 80 \\
\hline E. faecalis ATCC 29219 & $>320$ & $>320$ \\
\hline B. bronchiseptica ATCC 4617 & 10 & 20 \\
\hline A. baumanii ATCC 19606 & 160 & 160 \\
\hline K. pneumoniae ATCC 13882 & $>320$ & $>320$ \\
\hline B. cepacia ATCC 25416 & 160 & 160 \\
\hline P. aeruginosa ATCC 27853 & $>320$ & $>320$ \\
\hline S. maltophilia ATCC 13637 & 160 & 160 \\
\hline P. vulgaris ATCC 6896 & 160 & 160 \\
\hline P. mirabilis ATCC 12453 & 160 & 160 \\
\hline E. coli ATCC 25922 & $>320$ & $>320$ \\
\hline E. coli ATCC BAA-198 & $>320$ & $>320$ \\
\hline B. subtilis ATCC 6633 & $>206$ & $>206$ \\
\hline B. stearothermophilus ATCC 7953 & $>206$ & $>206$ \\
\hline C. albicans ATCC 90028 & $>320$ & $>320$ \\
\hline C. parapsilosis ATCC 22019 & 206 & $>206$ \\
\hline C. krusei ATCC 6258 & 206 & $>206$ \\
\hline
\end{tabular}

aMIC's of the reference compounds: penicillin G against $S$. aureus ATCC $43300,5.0 \mu \mathrm{g} \mathrm{ml}^{-1}$; polimyxin B against $P$. aeruginosa ATCC $27853,1.2 \mu \mathrm{g} \mathrm{ml}^{-1}$; amphotericin against $C$. krusei, $1 \mu \mathrm{gl}^{-1}$.

\section{Genotoxicity}

Bacillus subtilis M45 ( $\mathrm{rec}^{-}$) is devoid of the recombinant-based DNA repair mechanism and, therefore, is much more susceptible to genotoxic damage than its $\mathrm{rec}^{+}$counterpart, which is evidenced by a wider zone of growth inhibition for this strain around the reference genotoxin (4-nitroquinoline $\mathrm{N}$-oxide)-carrying discs. The diameter of the zone of growth inhibition reached $24 \mathrm{~mm}$ for the $\mathrm{rec}^{-}$strain and $12 \mathrm{~mm}$ for the $\mathrm{rec}^{+}$strain. The examined JS-1 alkaloid did not inhibit the growth of the tested $B$. subtilis strains and, hence, was determined as nongenotoxic. The lack of genotoxic features of JS-1 allows the consideration of potential modifications of the naturally isolated molecule to increase its antibacterial and antifungial activity.

\section{Antimicrobial activity}

JS-1 was tested against three Gram-positive bacteria, reference bacteria (Staphylococcus aureus subsp. aureus ATCC 25923; S. aureus subsp. aureus ATCC 43300 resistant to methicillin; and Enterococcus faecalis), 12 Gram-negative bacteria (Bordetella bronchiseptica; Stenotrophomonas maltophilia; Proteus vulgaris and P. mirabilis; Burkholderia cepacia; Acinetobacter baumanii; Klebsiella pneumoniae; Pseudomonas aeruginosa; Escherichia coli ATCC 25922; E. coli ATCC BAA-198-producing extended spectrum $\beta$-lactamase ESBL TEM-26; Bacillus subtilis; B. stearothermophilus) and three yeasts (Candida albicans; C. parapsilosis and C. krusei) by the broth microdilution method. MIC and MBC are presented in Table 2 . JS-1 exhibited the highest activity against B. bronchiseptica (MIC $10 \mu \mathrm{g} \mathrm{ml}^{-1}$ ) and $S$. aureus strains, including methicillin-resistant S. aureus (MIC $40-80 \mu \mathrm{g} \mathrm{ml}^{-1}$ ). Bacteria E. faecalis, $K$. pneumoniae, E. coli and $P$. aeruginosa, and the yeast $C$. albicans proved insensitive (MIC $>320 \mu \mathrm{g} \mathrm{ml}^{-1}$ ).

Antibiotic resistance has reached a crisis point in many hospitals around the world. The problem is related to methicillin-resistant $S$. aureus and to many multidrug-resistant Gram-negatives. ${ }^{13-15}$ Therefore, new classes of potent antimicrobial agents, including natural products, are needed to resolve this problem. 
Table 3 MICs of alkaloid JS-1 against clinical isolates of $S$. aureus

\begin{tabular}{lcc}
\hline Strains & MIC, $\left(\mu \mathrm{g} \mathrm{m}^{-1}\right)$ & Number of strains \\
\hline S. aureus (methicillin-resistant S. aureus) & 80 & 4 \\
& 103 & 6 \\
& 206 & 12 \\
& $>206$ & 5 \\
S. aureus (methicillin-sensitive S. aureus) & 103 & 1 \\
& 206 & 2 \\
& $>206$ & 1 \\
\hline
\end{tabular}

In addition, the activity of JS-1 alkaloid on 31 clinical isolates of S. aureus, including 27 S. aureus methicillin-resistant $S$. aureus strains, was examined. MIC values are presented in Table 3. Of the clinical isolates, 30\% exhibited sensitivity to the new compound (MIC 80$103 \mu \mathrm{g} \mathrm{ml}^{-1}$ ). The obtained MIC values of JS- 1 alkaloid for the clinical strains were similar to the MIC values determined for the $S$. aureus ATCC 25923 reference strain (MIC $80 \mu \mathrm{g} \mathrm{ml}^{-1}$ ). No differences between the sensitivity of clinical methicillin-resistant $S$. aureus and methicillinsensitive $S$. aureus strains toward JS-1 alkaloid have been observed.

On the contrary, the relatively poor MIC values of JS-1 in comparison with the good inhibitory activity of DD-peptidases was most probably associated with the weak permeability of the bacterial cell envelopes to the examined alkaloid. The inhibitory activity of JS-1 on DD-peptidases is comparable with the activity of certain $\beta$-lactam antibiotics. ${ }^{9}$ Yet, in bacteria, DD-peptidases are known to occur in the periplasmic space. Hence, most probably the structure of JS-1 (Figure 1), which suggests low lipophility of the molecule, impedes its transport to the periplasmic space.

JS-1, the novel DD-carboxypeptidases inhibitor isolated from the culture broth of Streptomyces sp. 8812, belongs to isoquinoline alkaloids, some of which exhibit antibacterial activity (for example, plant origin products such as berberine, canadaline, canadine, $(+)-\mathrm{N}$ (methoxycarbonyl)- $\mathrm{N}$-norboline). ${ }^{16,17}$ Some of them show an activity toward S. aureus, which is analogous to JS-1. Iwasa et al. ${ }^{18}$ described antimicrobial, antimalarial, cytotoxic and anti-HIV activities of simple, natural and synthetic isoquinoline and benzylisoquinoline alkaloids. Some simple alkaloids were significantly active in each assay; especially those with a quaternary nitrogen atom of isoquinolinum or dihydroisoquinolinum type may contribute to enhanced potency in the first three types of activites. ${ }^{18}$

This study reports the discovery of a simple isoquinoline alkaloid, JS-1, and its biological activity.

Specific inhibition of DD-peptidase activity (occurring solely in Prokaryota) by JS-1 alkaloid implies the directed action of this compound and its derivatives on bacteria. Moreover, the demonstrated lack of both genotoxic and hemolytic activities toward human blood cells suggests the possible application of the JS- 1 alkaloid as an initial compound in the search of a potentially new drug group. The active compound JS-1 must be studied further to determine its possible biological activity and toxicity thereof, and to resolve the mode of antibacterial action of isoquinoline alkaloids. Moreover, a synthetic modification of the natural molecule may generate new compounds with improved antibacterial activity.

\section{METHODS}

\section{Taxonomy}

The JS-1-producing actinomycetes strain, Streptomyces sp. 8812, was isolated from soil in Brasil. The strain, Streptomyces sp. 8812 , was grown at $28^{\circ} \mathrm{C}$ for 14 days on inorganic salts-starch agar, glycerol-asparagine agar, yeast extract-malt extract agar, tyrosine agar and on Czapek's medium and was examined visually to determine substrate mycelium pigmentation and spore color. Colors were determined by using the $\mathrm{H}$. Prauser Code. ${ }^{19}$ Morphological characteristics were observed with a scanning electron microscope (Jeol JSM-35, Tokyo, Japan). Standard biochemical properties of this strain were tested according to the methods of Williams et al. ${ }^{20}$ All carbon sources for carbon utilization tests were tested at the concentrations recommended by Shirling and Gottlieb ${ }^{21}$ and Williams et al. ${ }^{20}$

\section{Fermentation}

A slant culture of strain 8812 was inoculated into a 500-ml Erlenmeyer flask containing $40 \mathrm{ml}$ of liquid medium consisting of tryptone (Difco, Sparks, MD, USA) $17 \mathrm{~g}$, peptone (Difco) $4 \mathrm{~g}$, yeast extract (Difco) $5 \mathrm{~g}$, corn steep liquor (Cerestar, Milan, Italy) $10 \mathrm{~g}$, lactose $10 \mathrm{~g}, \mathrm{CaCO}_{3} 3 \mathrm{~g}, \mathrm{~K}_{2} \mathrm{HPO}_{4} 4 \mathrm{~g}$, $\mathrm{KH}_{2} \mathrm{PO}_{4} 2 \mathrm{~g}$ and $\mathrm{MgSO}_{4} \cdot 7 \mathrm{H}_{2} \mathrm{O} 0.5 \mathrm{~g}$ in 1.01 of tap water, $\mathrm{pH}$ 6.7. The inoculated flasks were incubated for $24 \mathrm{~h}$ on a rotary shaker $(220 \mathrm{r.p.m}$.) at $28^{\circ} \mathrm{C}$. A volume of $4 \mathrm{ml}$ of the seed culture was transferred into $500 \mathrm{ml}$ flasks containing $36 \mathrm{ml}$ of the same medium, and incubated on a rotary shaker (220 r.p.m.) at $28^{\circ} \mathrm{C}$. Fermentation was carried out for $22 \mathrm{~h}$. The production of JS-1 was analyzed by testing for DD-carboxypeptidase 64-575 II inhibition. After $22 \mathrm{~h}$ of fermentation, the amount of JS-1 in the broth filtrate reached a maximum (100\% inhibition of DD-peptidase 64-575 II activity).

\section{Assay of DD-carboxypeptidase activity}

Enzyme activity was measured as described previously.22 Samples for assay of DD-carboxypeptidase activity consisted of $10 \mu \mathrm{l}$ of exocellular DD-carboxypeptidase 64-575 II $(50 \mu \mathrm{M})$ from Saccharopolyspora erythraea 64-575 II (Polish Collection of Microorganism, Wroclaw, accession number B/00018), ${ }^{9,23} 10 \mu \mathrm{l}$ of the substrate solution containing $2.98 \mathrm{mg} \mathrm{ml}^{-1} \mathrm{~N}^{\alpha}, \mathrm{N}^{\varepsilon}$-diacetyl-L-lysyl-D-alanylD-alanine in $0.1 \mathrm{M}$ phosphate buffer, $\mathrm{pH} 8.0$, and $20 \mu \mathrm{l}$ of $0.1 \mathrm{M}$ phosphate buffer, $\mathrm{pH}$ 8.0. Standard sample contained $20 \mu \mathrm{l}$ of $\mathrm{D}$-alanine in distilled water. Samples were incubated for $30 \mathrm{~min}$ at $37^{\circ} \mathrm{C}$ and then boiled for $2 \mathrm{~min}$. After cooling, $77 \mu \mathrm{l}$ of the reaction mixture was added, and all samples were incubated for $10 \mathrm{~min}$ at $37^{\circ} \mathrm{C}$. Reaction mixture for assay of DD-carboxypeptidase activity consisted of $60 \mu \mathrm{l}$ of $0.05 \mathrm{mg} \mathrm{ml}^{-1}$ flavin adenine dinucleotide in $0.1 \mathrm{M}$ phosphate buffer, $\mathrm{pH} 8.0,10 \mu \mathrm{l}$ of $0.2 \mathrm{mg} \mathrm{ml}^{-1}$ horseradish peroxidase $\left(250-330 \mathrm{U} \mathrm{mg}^{-1}\right)$ in distilled water, $5 \mu \mathrm{l} \mathrm{of} 5 \mathrm{mg} \mathrm{ml}^{-1}$ of $o$-dianisidine- $\mathrm{HCl}$ in distilled water and $2 \mu \mathrm{l}$ of $11.9 \mathrm{mg} \mathrm{ml}^{-1}$ of D-amino acid oxidase from hog kidney $\left(20.7 \mathrm{U} \mathrm{mg}^{-1}\right)$ in $0.1 \mathrm{M}$ phosphate buffer, $\mathrm{pH}$ 8.0. Finally, $350 \mu \mathrm{l}$ of a mixture consisting of methanol, distilled water and sulfuric acid (5:5:6 by volume) was added to each sample. Absorbance of the resulting solution was measured spectrophotometrically at $540 \mathrm{~nm}$ (Jasco V-630, Tokyo, Japan).

\section{Assay of JS-1 inhibitory activity on DD-peptidases}

Inhibition of DD-peptidase 64-575 II by the JS-1 compound was evaluated as follows. To detect the active compound during cultivation of strain 8812 and in subsequent stages of JS-1 purification, the DD-peptidase 64-575 II inhibition test was carried out. Mixtures of $10 \mu \mathrm{l}$ of DD-peptidase 64-575 II $(50 \mu \mathrm{M}), 10 \mu \mathrm{l}$ of the supernatant (or aliquots of concentrated fractions during purification steps) and $10 \mu \mathrm{l}$ of $0.1 \mathrm{M}$ phosphate buffer $\mathrm{pH} 8.0$ were incubated for $30 \mathrm{~min}$ at $37^{\circ} \mathrm{C}$. After incubation, $10 \mu \mathrm{l}$ of the substrate solution was added to $30 \mu \mathrm{l}$ of each sample and the resulting mixtures were incubated again. The rest of the procedure was performed as mentioned above. To determine the inhibitory activity of the purified JS-1 alkaloid on DD-peptidase 64-575 II, the assay was performed as described above with the only exception being that the enzyme was incubated with JS-1 at different concentrations ranging from $0.1 \mathrm{~mm}$ to $0.1 \mu \mathrm{M}$ (instead of the supernatant). The inhibition of DD-peptidase was expressed as $\mathrm{IC}_{50}$ values, molar concentrations of JS-1 necessary to inhibit the DD-peptidase activity by $50 \%$.

The inhibition of exocellular DD-peptidase R39 from Actinomadura R39 ${ }^{24}$ by JS-1 was performed as described previously. DD-peptidase R39 of $10 \mu \mathrm{l}$ (Penzym test, UCB Bioproducts, Braine-l'Alleud, Belgium $)^{25}$ was used in the reaction mixtures. 


\section{Assay of the universal protease activity}

Pancreatic elastase (type IV) from porcine pancreas $\left(0.017 \mathrm{U} \mathrm{ml}^{-1}\right)$ was assayed by monitoring the release of p-nitroanilide at $410 \mathrm{~nm}$ from $0.3 \mathrm{~mm} N$-succinylAla-Ala-Val-Ala p-nitroanilide in $0.1 \mathrm{~m}$ Tris buffer, $\mathrm{pH} 8.0$, at $25^{\circ} \mathrm{C}^{26}$

Carboxypeptidase A from bovine pancreas $\left(0.4 \mathrm{U} \mathrm{ml}^{-1}\right)$ was assayed by examining hydrolysis at $254 \mathrm{~nm}$ of $1 \mathrm{~mm}$ Hippuryl-L-Phe in $0.025 \mathrm{M}$ Tris buffer with $0.5 \mathrm{M} \mathrm{NaCl}, \mathrm{pH} 7.5$, at $25^{\circ} \mathrm{C}^{27}$

Thrombin from bovine plasma $\left(3.7 \mathrm{U} \mathrm{ml}^{-1}\right)$ was assayed by monitoring the release of p-nitroanilide at $410 \mathrm{~nm}$ from $1 \mathrm{~mm} \mathrm{~N}$-Benzoyl-L-Arg p-nitroanilide in $10 \mathrm{~mm}$ HEPES, $10 \mathrm{~mm}$ Tris buffer, with $0.1 \mathrm{M} \mathrm{NaCl}, 0.1 \%$ PEG $_{6000}$ and $1 \%$ dimethylsulfoxide, $\mathrm{pH} 7.8$, at $25^{\circ} \mathrm{C} .{ }^{28}$

Trypsin from porcine pancreas $\left(73 \mathrm{U} \mathrm{ml}^{-1}\right)$ was assayed by monitoring the release of p-nitroanilide at $410 \mathrm{~nm}$ from $1 \mathrm{~mm} N$-Benzoyl-D,L-Arg p-nitroanilide in $0.1 \mathrm{M}$ Tris buffer with $20 \mathrm{mM} \mathrm{CaCl}_{2}, 1 \%$ dimethylsulfoxide, $\mathrm{pH} 8.0$, at $25^{\circ} \mathrm{C} \cdot 29,30$

Papain from Papaya latex $\left(2.5 \mathrm{U} \mathrm{ml}^{-1}\right)$ was assayed by examining the release at $410 \mathrm{~nm}$ of p-nitroanilide from $1 \mathrm{~mm} N$-Benzoyl-L-Arg p-nitroanilide in $0.1 \mathrm{M}$ phosphate buffer with $2 \mathrm{~mm}$ Cys, 2 mм EDTA, $1 \%$ dimethylsulfoxide, $\mathrm{pH}$ 7.0, at $25{ }^{\circ} \mathrm{C} .{ }^{31}$ Earlier, papain was activated by incubation at room temperature in the same buffer without dimethylsulfoxide for $1.5 \mathrm{~h}$.

Endoproteinase Glu-C from S. aureus V8 $\left(6.7 \mathrm{U} \mathrm{ml}^{-1}\right)$ was assayed by monitoring the release of p-nitroanilide from $1 \mathrm{~mm}$ Ac-Glu-p-nitroanilide in $0.1 \mathrm{M}$ Tris buffer, $\mathrm{pH} 8.0$, containing $2 \%$ dimethyl formamide and $2 \mathrm{mM} \mathrm{CaCl}_{2}$, at $37^{\circ} \mathrm{C}^{32}$

The activity of pepsin from porcine gastric mucosa $\left(30.3 \mathrm{Um}^{-1}\right)$ was assayed using $2.5 \%$ bovine hemoglobin as substrate, at acidic $\mathrm{pH}$ and at $37^{\circ} \mathrm{C}$. After $10 \mathrm{~min}$ of incubation, the reaction was stopped by the addition of $5 \%$ trichloroacetic acid. The samples were centrifuged and the resulting supernatant was analyzed at $280 \mathrm{~nm} .{ }^{33}$

All enzyme assays were performed using a spectrophotometer (Jasco V-630).

Assessment of the inhibition of the above-listed proteolytic enzymes was carried out by preincubating the enzymes with JS- 1 at a concentration of $65 \mu \mathrm{M}$, which causes 100\% inhibition of DD-peptidase 64-575 II activity and, additionally, at a concentration twofold greater.

\section{Assay of $\beta$-lactamase activity}

Inhibition of penicillinase (Penase, $5 \times 10^{6} \mathrm{IU} \mathrm{ml}^{-1}$ ) by the JS- 1 compound was evaluated on the basis of the method described in literature. ${ }^{34} \mathrm{~A}$ mixture of $\beta$-lactamase and JS-1 in $0.1 \mathrm{~m}$ phosphate buffer, $\mathrm{pH} 7.0$, was incubated for $30 \mathrm{~min}$ at $37^{\circ} \mathrm{C}$; thereafter, nitrocephin was added and the mixture was incubated for an additional $10 \mathrm{~min}$ at $37^{\circ} \mathrm{C}$. Subsequently, absorbance was measured at $482 \mathrm{~nm}$.

\section{Antimicrobial activity}

The antimicrobial spectrum of JS- 1 was evaluated by the MIC method using the serial twofold dilution method under standard conditions as described in the Committee Laboratory Standards (CLSI) reference method M7-A7. ${ }^{35}$ Test reference bacterial strains are presented in Table 2. The organisms were cultivated according to ATCC recommendation. Thirty-one clinical isolates of $S$. aureus, including 27 methicillin-resistant $S$. aureus strains, were cultivated on tryptic soy agar. All strains were incubated for $24 \mathrm{~h}$ at $37^{\circ} \mathrm{C}$.

The reference method (broth microdilution susceptibility test) was as follows: The compound JS-1 was dissolved in double-distilled water. A series of the twofold JS-1 alkaloid dilutions were diluted with cation-adjusted Mueller-Hinton broth. Aliquots of $95 \mu \mathrm{l}$ were dispensed into microdilution sterile plates (Mar-Four). Then, $5 \mu \mathrm{l}$ of bacteria inoculum, containing $5 \times 10^{4}$ $\mathrm{CFU} \mathrm{ml}{ }^{-1}$, was added. The final concentration of the JS- 1 compound ranged from 320 to $5 \mu \mathrm{g} \mathrm{ml}^{-1}$ (or 206-12.9 $\mu \mathrm{g} \mathrm{ml}^{-1}$ ), all in twofold dilution steps. The experiments for each sample were conducted in triplicate. Polymyxin B and penicillin $\mathrm{G}$ were used as controls (from 8 to $0.15 \mu \mathrm{g} \mathrm{ml}^{-1}$ ). The plates were incubated at $37^{\circ} \mathrm{C}\left(35^{\circ} \mathrm{C}\right)$ for $18-24 \mathrm{~h}$ depending on the bacterial strain. MIC was defined as the lowest drug concentration that reduced growth by $100 \%$. For the $\mathrm{MBC}$ assay, aliquots $(10 \mu \mathrm{l})$ of each culture without visible growth were transferred onto tryptic soy agar and incubated during $24 \mathrm{~h}$ at $37^{\circ} \mathrm{C}$.

Reference yeasts were presented in Table 2. Candida sp. was cultivated according to ATCC references. The broth microdilution susceptibility test was performed as described in Clinical and Laboratory Standards Institute, reference method M27-A2 (1). ${ }^{36}$

\section{Hemolysis test}

The hemolysis test was evaluated following the literature method. ${ }^{37}$ Red blood cells prepared in phosphate-buffered saline were suspended to correspond to a hematocrit of $1 \%$ in JS- 1 alkaloid at final concentrations of 0.6 and $2.4 \mathrm{~mm}$ and were incubated for $30,60,90,120$ and $180 \mathrm{~min}$ at $23^{\circ} \mathrm{C}$

\section{Genotoxicity}

For genotoxicity research, two genetically modified B. subtilis strains, M45 rec and $\mathrm{H} 17 \mathrm{rec}^{+}$, obtained from Dr Sadaie were studied. ${ }^{38-40}$ The JS- 1 alkaloid was examined by the disc-diffusion method according to Kada's procedure. ${ }^{38,39}$ Sterile filter paper discs ( $9 \mathrm{~mm}$ diameter, Whatman no. 3, Maidstone, UK) were dripped with tested JS-1 solution to load $206 \mu \mathrm{g}$ of the compound per disc. As a standard, 4-nitroquinoline $\mathrm{N}$-oxide ( $2 \mu \mathrm{g}$ per disc) was used. Results of the genotoxicity test were read after $18 \mathrm{~h}$ of incubation of the discs at $35^{\circ} \mathrm{C}$.

\section{ACKNOWLEDGEMENTS}

We are grateful to Professor Jean-Maria Ghuysen (Centre for Protein Engineering and Laboratoire d'Enzymologie, Université de Liège, Belgium) for kindly providing us with DD-peptidase R39. We thank Professor Stefan Tyski (Department of Pharmaceutical Microbiology, Medical University of Warsaw, Warsaw, Poland) for obtaining clinical strains of $S$. aureus.

1 Walsh, C. T. Antibiotics: Actions, Origin, Resistance (ASM Press, Washington, DC, 2003).

2 Baker, D. D., Chu, M., Oza, U. \& Rajgarhia, V. The value of natural products to future pharmaceutical discovery. Nat. Prod. Rep. 24, 1225-1244 (2007).

3 Imanaka, H. Screening microbial products for medicine. Actinomycetologica 14, 22-26 (2001)

4 Singh, M. P. \& Greenstein, M. Antibacterial leads from microbial natural products discovery. Curr. Opin. Drug Disc. Develop. 3, 167-176 (2000).

5 Berdy, J. Bioactive microbial metabolites. J. Antibiot. 58, 1-26 (2005).

6 Waxman, D. J. \& Strominger, J. L. Penicillin-binding proteins and the mechanism of action of $\beta$-lactam antibiotics. Ann. Rev. Biochem. 52, 825-969 (1983).

7 Ghuysen, J.-M. Bacterial active-site serine penicillin-interactive proteins and domains: mechanism, structure, and evolution. Rev. Infect. Dis. 10, 726-732 (1988).

8 Kurzatkowski, W., Solecka, J., Filipek, J., Kurzatkowski, J. D. \& Kurylowicz, W. Streptomycetes excreting DD-carboxypeptidases. Appl. Microbiol. Biotechnol. 33, 452-454 (1990).

9 Solecka, J. \& Kurzatkowski, W. Affinity of exocellular DD-carboxypeptidase/transpeptidase from Saccharopolyspora erythraea PZH 64-575 to beta-lactam compounds. Med. Dosw. Mikrobiol. 51, 151-165 (1999).

10 Solecka, J. \& Kozerski, L. A new inhibitor of DD-peptidase and its use as antibiotic or anticancer drug. PCT/WO 2009/028972 A1, 5 March (2009).

11 Solecka, J. et al. A novel isoquinoline alkaloid, DD-carboxypeptidase inhibitor, with antimicrobial activity isolated from Streptomyces sp. 8812. Part II: Physico-chemical properties and structure elucidation. J. Antibiot. (e-pub ahead of print 28 August 2009; doi:10.1038/ja.2009.86).

12 Dusart, J. et al. DD-Carboxypeptidase-transpeptidase and killing site of $\beta$-lactam antibiotics in Streptomyces strains R39, R61, and K11. Antimicrob. Ag. Chemother. 3, 181-187 (1973)

13 Gould, I. M. The epidemiology of antibiotic resistance. Int. J Antimicrob. Agents 32S, S2-S9 (2008).

14 Casey, A. L., Lambert, P. A. \& Elliott, T. S. J. Staphylococci. Int. J Antimicrob. Agents 29 (Suppl. 3), S23-S32 (2007)

15 Denton, M. Enterobacteriaceae. Int. J Antimicrob. Agents 29(Suppl. 3), S9-S22 (2007).

16 Scazzocchio, F., Cometa, M. F., Tomassini, L. \& Palmery, M. Antibacterial activity of Hydrastis canadensis extract and its major isolated alkaloids. Planta Med. 67, 561-564 (2001).

17 Feng, T., Xu, Y., Cai, X.-H., Du, Z.-Z. \& Luo, X.-D. Antimicrobially active isoquinoline alkaloids from Litsea cubeba. Planta Med. 75, 76-79 (2009).

18 Iwasa, K. et al. Simple isoquinoline and benzylisoquinoline alkaloids as potential antimicrobial, antimalarial, cytotoxic, and anti-HIV agents. Bioorg. Med. Chem. 9 , 2871-2884 (2001)

19 Prauser, H. Aptness and application of colour codes for exact description of colours of streptomycetes. Z. Allg. Mikrobiologie 4, 95-98 (1964).

20 Williams, S. T., Goodfellow, M. \& Alderson, G. Genus Streptomyces Waksman and Henrici 1943. in Bergey's Manual of Systematic Bacteriology, Vol. 4 (ed. Williams, S. T.) 2452-2492 (Williams \& Wilkins, Baltimore, 1989).

21 Shirling, E. B. \& Gottlieb, D. Methods for characterization of Streptomyces species. Int. J. Syst. Bacteriol. 16, 313-340 (1966). 
22 Frère, J. M., Leyh-Bouille, M., Ghuysen, J. M., Nieto, M. \& Perkins, H. R. Exocellular DD-carboxypeptidases/transpeptidases from Streptomyces. Methods Enzymol. 45, 610-636 (1976).

23 Solecka, J., Łysek, R., Furman, B., Chmielewski, M. \& Kurzątkowski, W. Practical use of DD-peptidase 64-575 for assay inhibition activity of natural and synthetic $\beta$-lactam compounds. Acta. Poloniae Pharmaceutica 60, 115-118 (2003).

24 Frère, J.-M. et al. Molecular weight, amino acid composition and physicochemical properties of the exocellular DD-carboxypeptidase-transpeptidase of Streptomyces R39. Biochem. J. 143, 233-240 (1974).

25 Sternesjo, A. \& Gustavsson, E. Biosensor analysis of [beta]-lactams I milk using the carboxypeptidase activity of a bacterial penicillin binding protein. J. AOAC Int. 89, 832-837 (2006).

26 Bieth, J., Spiess, B. \& Wermuth, C. G. Synthesis and analytical use of highly sensitive an convenient substrate of elastase. Biochem. Medicine 11, 350-357 (1974).

27 Hass, G. M. \& Ryan, C. A. Carboxypeptidase inhibitor from potatoes. Methods Enzymol. 80, 778-791 (1981).

28 Bezeaud, A. \& Guillin, M.-C. Enzymatic and nonenzymic properties of human B-thrombin. J. Biol. Chem. 263, 3576-3581 (1988).

29 Erlanger, B. F., Edel, F. \& Cooper, A. G. The action of chymotrypsin on two new chromogenic substrates. Arch. Biochem. Biophys. 210, 206-210 (1966).

30 Kassell, B. Bovine trypsin-kallikrein inhibitor (kunits inhibitor, basic pancreatic inhibitor, polyvalent inhibitor from bovine organs). Methods Enzymol. 19, 844-852 (1970).

31 Mole, J. \& Horton, H. R. Kinetics of papain-catalyzed hydrolysis of $\alpha$ - $N$-benzoylL-arginine-p-nitroanilide. Biochemistry 12, 816-822 (1973).
32 Kakudo, S. et al. Purification, characterization, cloning, and expressin of a glutamic acid-specific protease from Bacillus licheniformis ATCC 14580. J. Biol. Chem. 267, 23782-23788 (1992).

33 Anson, M. L. The estimation of pepsin, trypsin, papain, and cathepsin with hemoglobin. J. Gen. Physiol. 22, 79-89 (1938).

34 O'Callaghan, C. H., Morris, A., Kirby, S. M. \& Shingler, A. H. Novel method for detection of $\beta$-lactamases by using a chromogenic cephalosporin substrate. Antimicrob. Ag. Chemother. 1, 283-288 (1972).

$35 \mathrm{CLSI}$. Method for Dilution Antimicrobial Susceptibility Test for Bacteria That Grow Aerobically; Approved Standard-Seventh Edition. M7-A7 [ISBN 1-56238-587-9]. CLSI, 940 West Valley Road, Suite 1400, Wayne, Pennsylvania 19087-1898, USA (2006).

36 CLSI. Reference Method for Broth Dilution Antifungal Susceptibility Testing of Yeast; Approved Standard-Second Edition. M27-A2, CLSI, Wayne, PA, USA (2002).

37 Dehghan-Noudeh, G., Housaindokht, M. \& Bazzaz,, B. S. F. Isolation, characterization, and investigation of surface and hemolytic activites of a lipopeptide biosurfactant produced by Bacillus subtilis ATCC 6633. J. Microbiol. 43, 272-276 (2005).

38 Kada, T., Moriya, M. \& Shirasu, Y. Screening of pesticides for DNA interactions by 'recassay' and mutagenesis testing, and frameshift mutagens detected. Mutat. Res. 26, 243-248 (1974).

39 Kada, T., Hirano, K. \& Shirasu, Y. Bacillus subtilis rec-assay test. in Chemical Mutagenesis Vol. 6 (eds de Sevres, F. E. \& Hollaender, A.) 149 (Plenum Press, New York, 1980).

40 Sadaie, T. \& Kada, T. Recombination-deficient mutants of Bacillus subtilis. J. Bacteriol. 125, 489-500 (1976). 